\title{
Palladium and Platinum complexes with pyridyl thiolate selenium (IV) and (o-aminophenylthiolato) selenium (IV)
}

\author{
N.H.Buttrus $^{1 *}$, T.J.Mohamad ${ }^{2}$ and S.A.Mallo ${ }^{2}$ \\ 1 - Department of Chemistry, College of Science,Mosul University \\ 2 - Department of Chemistry, College of Science, Dohouk University \\ Received \\ Accepted \\ 13/11/2006 \\ 9/1/2007
}

\section{الخلاصة}

يتقاعل فلز السلينيوم مع ثنائي اثليلين ثنائي الكبريت او ثنائي بريديل ثنائي الكبريت في

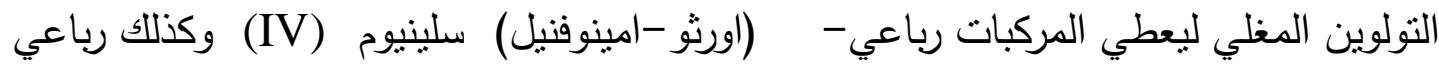
[

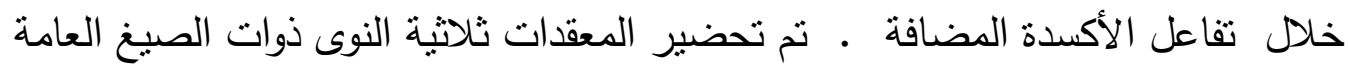
و Pd(II ) = M \} حيث $\left[\mathrm{Se}\left(\mathrm{SC}_{5} \mathrm{H}_{4} \mathrm{~N}\right)_{4}\left(\mathrm{MCl}_{2}\right)_{2}\right]$ و [Se( $\left.\left(\mathrm{SC}_{6} \mathrm{H}_{4} \mathrm{NH}_{2}-O\right)_{4}\left(\mathrm{MCl}_{2}\right)_{2}\right]$

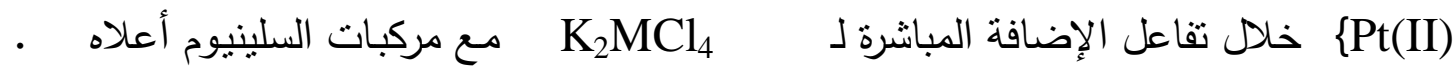
كذللك تم تحضير المعقدات ذوات الصيغ و[ خلال تفاعل الاستبدال لايون الكلوريد وتم تتخيص المعقدات

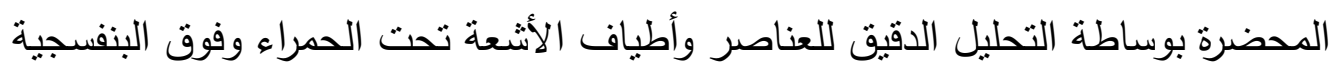
والتوصيلية والقياسات المغناطيسية.
\end{abstract}

\begin{abstract}
Selenium metal react with di-o-anlinedisulfide or di-2-pyridyldisulfide in refluxing toluene to give the compounds tetrakis- $(o-$ aminophenyl- thiolato) selenium (IV) and tetrakis-(pyridylthiolato) selenium (IV), $\left[\mathrm{Se}\left(\mathrm{SC}_{6} \mathrm{H}_{4} \mathrm{NH}_{2}-O\right)_{4}\right]$ and $\left[\mathrm{Se}\left(\mathrm{SC}_{5} \mathrm{H}_{4} \mathrm{~N}\right)_{4}\right]$, through an oxidative addition reaction. Trinuclear complexes of the general formula [Se( $\left.\left(\mathrm{SC}_{6} \mathrm{H}_{4} \mathrm{NH}_{2}-O\right)_{4}\left(\mathrm{MCl}_{2}\right)_{2}\right]$ and $\left[\mathrm{Se}\left(\mathrm{SC}_{5} \mathrm{H}_{4} \mathrm{~N}\right)_{4}\left(\mathrm{MCl}_{2}\right)_{2}\right], \quad\{\mathrm{M}=\mathrm{Pd}(\mathrm{III})$ or $\mathrm{Pt}(\mathrm{II})\}$ were prepared by direct reaction of $\mathrm{K}_{2} \mathrm{MCl}_{4}$ with the selenium compounds. Complexes of the general formula $\left[\mathrm{SeM}_{2}\left(\mathrm{SC}_{6} \mathrm{H}_{4} \mathrm{NH}_{2}-O\right)_{4}\right.$ $\left.(\mathrm{SPh})_{4}\right]$ and $\left[\mathrm{Se} \mathrm{M}_{2}\left(\mathrm{SC}_{5} \mathrm{H}_{4} \mathrm{~N}\right)_{4}(\mathrm{SPh})_{4}\right]$ were also prepared through neuclephilic substitution reaction. The prepared complexes were characterized by their elemental analysis, IR and UV/Vis spectroscopy, conductivity and magnetic measurements.
\end{abstract}

* Correspondance another 


\section{Introduction:}

The importance of metal-dithiolene complexes has increased in recent years due to their applications in the field of new molecular materials. Solids that exhibit electrical ${ }^{(1)}$ and magnetic properties ${ }^{(2)}$ near infrared dyes ${ }^{(3)}$ and non-linear optical material ${ }^{(4)}$ based on metaldithiolene have been reported.

Interest has developed in thioether complexes of nickel ${ }^{(5)}$ because of the discovery that a number of hydrogenases contain nickel with several sulfur in the coordination sphere at the enzyme active site ${ }^{(6)}$. Complexes of group 6 and group 8 transition metals with thioether have been examined extensively ${ }^{(7,8)}$ because of their steriochemically non rigid properties and interest continues in the consequences and applications of these metal complexes ${ }^{(9-11)}$.

The complex $\left[\mathrm{Pd}_{2} \mathrm{Cl}_{2}(\mathrm{dmp})_{2}\right], \quad[\mathrm{dmp}=2$-(dimethyaminomethyl) phenyl] reacts with 1-H-pyridine-2-thione(PySH) or with the 6-methyl substituted derivatives (mPySH) to generate the dinuclear complexes $\left[\mathrm{Pd}_{2}(\mathrm{dmp})_{2}(\mathrm{PyS})_{2}\right]$ and $\left[\mathrm{Pd}_{2}(\mathrm{dmp})_{2}(\mathrm{mPyS})_{2}\right]$. The complex $\left[\mathrm{Pd}_{3}(\mathrm{dmp})_{3}(\mathrm{PyS})_{2}\right]^{+}$were prepared by the reaction of these complexes with another mole of the starting complex and were studied by x-ray crystal structure were reported by Deeming et al. ${ }^{(12)}$.

Complexes of general formula $\left[\mathrm{M}(\mathrm{L}) \mathrm{Cl}_{2}\right], \mathrm{M}=\mathrm{Pd}^{+2}$ or $\mathrm{Pt}^{+2}, \mathrm{~L}=4[\mathrm{~N}-$ (furan-2'-carboxalidene)amino] antipyrine thiosemicarbazone and $\left[\mathrm{M}(\mathrm{L}) \mathrm{Cl}_{3}\right], \mathrm{M}=\mathrm{Ru}^{+3}, \mathrm{Rh}^{+3}$ or $\mathrm{Ir}^{+3}$, were prepared and characterized by physical, chemical ,spectral data, Magnetic and electronic spectra suggest that $\mathrm{Pd}^{+2} \& \mathrm{Pt}^{+2}$ complexes are square planer while $\mathrm{Ru}^{+3}, \mathrm{Rh}^{+3}$ and $\mathrm{Ir}^{+3}$ complexes have octahedral geometry were reported by Agrawal and Prasad $^{(13)}$.

In view of these interesting results and as continuation of our comprehensive studies on transition and non-transition metal complexes with sulfur containing ligand (14-17), we have prepared trinuclear complexes through adducts formation with selenium compounds [Se $\left.\left(\mathrm{SC}_{4} \mathrm{H}_{3} \mathrm{~N}\right)_{4}\right]$ and $\left[\mathrm{Se}\left(\mathrm{C}_{6} \mathrm{H}_{4} \mathrm{NH}_{2}-O\right)_{4}\right]$ which were prepared by oxidative addition of di-2-pyridyl disulfide or di-o-aniline disulfide also represented the replacement reactions of chloride ion attached to the metal ions by thiophenoxide ion.

\section{Experimental:}

IR spectra were recorded on a Perkin-Elmer 580B IR spectrophotometer in the range (4000-200) $\mathrm{cm}^{-1}$ range using Nujol mulls or CsI discs. The metal content was estimated spectrometically using Shimadzu AA670.Conductivity measurements were made on $10^{-3} \mathrm{M}$ solution of the complexes in dimethylsulfoxide (DMSO) at ambient temperature using conductivity meter model 4070 Jenway. Electronic 
spectra were recorded on Shimadzu UV/Vis spectrophotometer UV-160 for $10^{-3} \mathrm{M}$ solution of the complexes in DMSO using $1 \mathrm{~cm}$ quartz cell. The magnetic measurements were carried out at $25^{\circ} \mathrm{C}$ on the solid state by Faraday's method using Bruker BM6 instrument.

The compounds $\left[\mathrm{Se}\left(\mathrm{SC}_{6} \mathrm{H}_{4} \mathrm{NH}_{2}-O\right)_{4}\right]$ and $\left[\mathrm{Se}\left(\mathrm{SC}_{4} \mathrm{H}_{3} \mathrm{~N}\right)_{4}\right]$ were prepared according to a literature metal ${ }^{(14)}$. The metal salts were used as supplied by Fluka.

\section{Preparation of $\left[\mathrm{Se}(\mathrm{L})_{4}\left(\mathrm{MCl}_{2}\right)_{2}\right]$ complexes:}

$\mathrm{M}=\mathrm{Pd}, \mathrm{Pt}, \mathrm{L}=\left\{\left(\mathrm{SC}_{6} \mathrm{H}_{4} \mathrm{NH}_{2}-O\right)_{4}\right\}$ or $\left\{\left(\mathrm{SC}_{4} \mathrm{H}_{3} \mathrm{~N}\right)_{4}\right\}$.

A clear solution of $\left[\mathrm{Se}(\mathrm{L})_{4}\right](1 \mathrm{mmol})$ in methanol $(10 \mathrm{ml})$ was added to a solution of $\mathrm{K}_{2} \mathrm{MCl}_{4}(\mathrm{M}=\mathrm{Pd}$ or $\mathrm{Pt})(2 \mathrm{mmol})$ in distilled water (10ml). A rapid formation of precipitate was observed, the mixture was stirred under reflux for ca $2 \mathrm{~h}$. The solid thus obtained was filtered off, washed with warm water, methanol then diethylether and dried under vacuum for several hours.

\section{Preparation of $\left[\mathrm{SeM}_{2}(\mathbf{L})_{4}(\mathbf{S P h})_{4}\right]$ :}

Trinuclear complex $\left[\mathrm{Se}(\mathrm{L})_{4}\left(\mathrm{MCl}_{2}\right)_{2}\right] \quad(1 \mathrm{mmol})$ dissolved in dimethylformamide (DMF) (10ml) was added with constant stirring to a solution containing equimolar quantities of thiophenol and potassium hydroxide in ethanol $(30 \mathrm{ml})$. The mixture was stirred under reflux for ca $1 \mathrm{~h}$. to ensure the completion of the reaction. The complexes thus precipitated, filtered off and washed with warm water and diethylether then dried under vacuum for several hours.

\section{Results and discussion:}

The compounds $\left[\mathrm{Se}\left(\mathrm{SC}_{6} \mathrm{H}_{4} \mathrm{NH}_{2}-O\right)_{4}\right]$ and $\left[\mathrm{Se}\left(\mathrm{SC}_{4} \mathrm{H}_{5} \mathrm{~N}\right)_{4}\right]$ were prepared through an oxidative addition reaction. These reactions are noticeably simpler than those used in the past for the preparation of compounds of the main group elements of the formula $\mathrm{M}(\mathrm{SPh})_{\mathrm{n}}$ which involved metathesis reactions of $\mathrm{MCl}_{n}$ with $\mathrm{Na}(\mathrm{SPh})$ or $\mathrm{Mg}(\mathrm{SPh})_{2}{ }^{(18)}$. The complexes of the type $\left[\mathrm{Se}(\mathrm{L})_{4}\left(\mathrm{MCl}_{2}\right)_{2}\right]$ were prepared by direct reaction of the selenium compound with metal chloride in 1:2 molar ratio. The complexes of the type $\left[\mathrm{SeM}_{2}(\mathrm{~L})_{4}(\mathrm{SPh})_{2}\right]$ were prepared by treating equimolar quantities of thiophenoxide (prepared from equimolar quantities of $\mathrm{KOH}$ and $\left.\mathrm{C}_{6} \mathrm{H}_{5} \mathrm{SH}\right)$ and the $\left[\mathrm{Se}(\mathrm{L})_{4}\left(\mathrm{MCl}_{2}\right)_{2}\right]$ complexes.

The analytical data of the compounds and complexes are given in (Table 1). These data are in a good agreement with the proposed formulae. All compounds are air-stable at room temperature and insoluble in the common organic solvents but they are soluble in DMF or DMSO. 
The molar conductance of the present complexes in DMSO are presented in (Table 1). The molar conductance values are too low to account for any dissociation, therefore, we consider that all these complexes are non-electrolytes ${ }^{(19)}$.

A study and comparison of infrared spectra of the compounds and their palladium and platinum metal complexes (Table 2) imply that the ligands behaves as monodentate and attached to selenium metal in an ion form through sulfur atoms, in complexes the coordination occur via $\mathrm{S}-\mathrm{Se}-\mathrm{S}$ linkage forming four member chelate ring (Fig 1). Strong bands in the $3390-3290 \mathrm{~cm}^{-1}$ and $1580-1590 \mathrm{~cm}^{-1}$ region in the compounds and complexes due to $v(\mathrm{NH})$ and $v(\mathrm{C}=\mathrm{N})$ vibrations. The negligible effect on these frequencies after complexation precludes the possibility of complexation at these groups. The frequency of $v(C-S)$ band observed at $1030-1040 \mathrm{~cm}^{-1}$ in the compounds is slightly decreased upon complexation with $\mathrm{MCl}_{2}$ to form the corresponding trinuclear complexes. Further support for the formation of new complexes is provided by the appearance of new band with in the $340-380$ or $400 \mathrm{~cm}^{-1}$ range characteristic of bidentate tetrathioselenium

Furthermore, the IR spectra of the complexes showed another band within the $320-290 \mathrm{~cm}^{-1}$ range which may be due to $v(\mathrm{M}-\mathrm{Cl})^{(21)}$. This band is split into two bands which can be considered as evidence for square planar cis-arrangement of the complexes.

In the $\left[\mathrm{SeM}_{2}(\mathrm{~L})_{4}(\mathrm{SPh})_{4}\right]$ complexes similar observation was found in the IR spectra as above, except the absences of any band due to $v(\mathrm{M}-\mathrm{Cl})$ absorption which indicate complete substitution of the thiophenol in the complexes. This observation is also confirmed by sodium fusion test.

The magnetic moment of $\mathrm{Pd}^{+2}$ and $\mathrm{Pt}^{+2}$ complexes indicate that these complexes are diamagnetic. The complexes may have a squareplanar coordination of the central metal ion by the surrounding ligands. $\mathrm{Pd}^{+2}$ and $\mathrm{Pt}^{+2}$ have $\mathrm{a} \mathrm{d}^{8}$ configuration favors the formation of complexes with square-planar geometry. In the electronic spectra (Table 2) of the present complexes, two spin allowed d-d bands in the $25000-29000 \mathrm{~cm}^{-1}$ region along with two charge transfer bands were observed. The spin allowed transition were assigned as a combination of both ${ }^{1} \mathrm{~A}_{1} \mathrm{~g} \longrightarrow{ }^{1} \mathrm{~A}_{2} \mathrm{~g}$ and ${ }^{1} \mathrm{~A}_{1} \mathrm{~g} \longrightarrow{ }^{1} \mathrm{Eg}$. The other spin allowed bands were assigned to the ${ }^{1} \mathrm{~A}_{1} \mathrm{~g} \longrightarrow \mathrm{B}_{1} \mathrm{~g}$ transition.

The electronic spectrum of the compounds are observed at 33910$35000 \mathrm{~cm}^{-1}$ range which may be assigned to charge transfer from ligand to selenium metal. 
The electronic spectra of these complexes are indicative of planar geometries and our data are in good agreement with previous reports $^{(22-24)}$.

On the basis of above studies, we tentatively assigned the following structures of the present complexes Fig 1.<smiles></smiles><smiles>Nc1ccccc1SS[As](Sc1ccccc1N)Sc1ccccc1N</smiles>

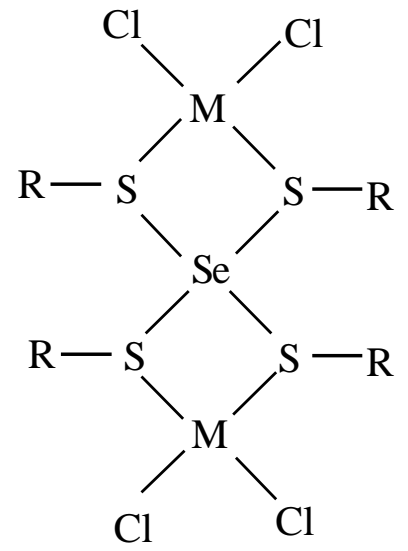

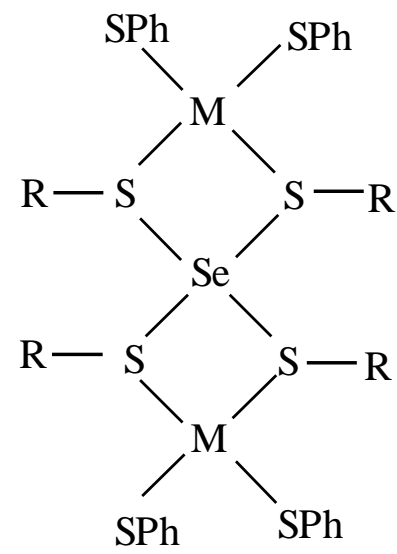<smiles></smiles>

Fig 1: Probable structure $\mathrm{Se}^{+4}$ of $\mathrm{Pd}^{+2}$ and $\mathrm{Pt}^{+2}$ compounds and complexes 



\section{J.Edu. Sci , Vol. (19) No.(3) 2007}

Table 1: Physical properties of compounds and complexes

\begin{tabular}{|c|c|c|c|c|c|c|c|c|c|c|}
\hline \multirow{2}{*}{ No. } & \multirow{2}{*}{ Compound } & \multirow{2}{*}{$\begin{array}{l}\text { M.p } \\
\left({ }^{\circ} \mathbf{c}\right)\end{array}$} & \multirow{2}{*}{ Colour } & \multirow{2}{*}{$\begin{array}{l}\text { Yield } \\
(\%)\end{array}$} & \multicolumn{5}{|c|}{ Analysis found (calcd.)* \% } & \multirow{2}{*}{$\underset{\mathrm{ohm}^{1} \cdot \mathrm{cm}^{2} \cdot \mathrm{mol}^{-1}}{\mathbf{S}^{-1}}$} \\
\hline & & & & & $\mathbf{C}$ & $\mathbf{H}$ & $\mathbf{N}$ & Se & $\mathbf{M}$ & \\
\hline 1 & {$\left[\mathrm{Se}\left(\mathrm{SC}_{5} \mathrm{H}_{4} \mathrm{~N}\right)_{4}\right]$} & 358 & Pale blue & 93 & $\begin{array}{c}45.98 \\
(46.24)\end{array}$ & $\begin{array}{c}2.99 \\
(3.08)\end{array}$ & $\begin{array}{c}10.65 \\
(10.79)\end{array}$ & $\begin{array}{c}15.49 \\
(15.52)\end{array}$ & --- & 14 \\
\hline 2 & {$\left[\mathrm{Se}\left(\mathrm{SC}_{6} \mathrm{H}_{4} \mathrm{NH}_{2}-O\right)_{4}\right]$} & 220 & brown & 89 & $\begin{array}{c}\mathbf{5 0 . 0 0} \\
(\mathbf{5 0 . 0 8})\end{array}$ & $\begin{array}{c}4.15 \\
(4.17)\end{array}$ & $\begin{array}{c}9.72 \\
(9.74)\end{array}$ & $\begin{array}{c}13.51 \\
(13.73)\end{array}$ & --- & 10 \\
\hline 3 & {$\left[\mathrm{Se}\left(\mathrm{SC}_{5} \mathrm{H}_{4} \mathrm{~N}\right)_{4}\left(\mathrm{PdCl}_{2}\right)_{2}\right]$} & 300 & Dark brown & 80 & $\begin{array}{c}27.39 \\
(27.47)\end{array}$ & $\begin{array}{c}1.80 \\
(1.83)\end{array}$ & $\begin{array}{c}6.89 \\
(6.41)\end{array}$ & $\begin{array}{c}9.00 \\
(9.04)\end{array}$ & $\begin{array}{c}24.29 \\
(24.35)\end{array}$ & 18 \\
\hline 4 & {$\left[\mathrm{Se}\left(\mathrm{SC}_{5} \mathrm{H}_{4} \mathrm{~N}\right)_{4}\left(\mathrm{PtCl}_{2}\right)_{2}\right]$} & 320 & black & 85 & $\begin{array}{c}22.79 \\
(22.83)\end{array}$ & $\begin{array}{c}1.50 \\
(1.52)\end{array}$ & $\begin{array}{c}5.31 \\
(5.33)\end{array}$ & $\begin{array}{c}7.43 \\
(7.52)\end{array}$ & $\begin{array}{c}37.03 \\
(37.11)\end{array}$ & 17 \\
\hline 5 & {$\left[\mathrm{Se}\left(\mathrm{SC}_{6} \mathrm{H}_{4} \mathrm{NH}_{2}-\mathrm{O}\right)_{4}\left(\mathrm{PdCl}_{2}\right)_{2}\right]$} & 335 & Dark brown & 72 & $\begin{array}{l}(30.79) \\
(30.98)\end{array}$ & $\begin{array}{c}2.51 \\
(2.54)\end{array}$ & $\begin{array}{c}6.00 \\
(6.02)\end{array}$ & $\begin{array}{c}8.41 \\
(8.49)\end{array}$ & $\begin{array}{c}22.81 \\
(22.89)\end{array}$ & 15 \\
\hline 6 & {$\left[\mathrm{Se}\left(\mathrm{SC}_{6} \mathrm{H}_{4} \mathrm{NH}_{2}-O\right)_{4}\left(\mathrm{PtCl}_{2}\right)_{2}\right]$} & 350 & Dark green & 75 & $\begin{array}{c}25.99 \\
(26.01)\end{array}$ & $\begin{array}{c}2.12 \\
(2.16)\end{array}$ & $\begin{array}{c}5.01 \\
(5.06)\end{array}$ & $\begin{array}{c}7.09 \\
(7.14)\end{array}$ & $\begin{array}{c}\text { 35.20 } \\
(35.23)\end{array}$ & 20 \\
\hline 7 & {$\left[\mathrm{Se} \mathrm{Pd}_{2}\left(\mathrm{SC}_{5} \mathrm{H}_{4} \mathrm{~N}\right)_{4}(\mathrm{SPh})_{4}\right]$} & 280 & Pale brown & 65 & $\begin{array}{r}44.19 \\
(45.21) \\
\end{array}$ & $\begin{array}{c}\mathbf{3 . 0 5} \\
(\mathbf{3 . 0 8}) \\
\end{array}$ & $\begin{array}{c}4.72 \\
(4.79)\end{array}$ & $\begin{array}{c}6.71 \\
(6.76)\end{array}$ & $\begin{array}{c}18.20 \\
(18.24)\end{array}$ & 16 \\
\hline 8 & {$\left[\mathrm{Se} \mathrm{Pt}_{2}\left(\mathrm{SC}_{5} \mathrm{H}_{4} \mathrm{~N}\right)_{4}(\mathrm{SPh})_{4}\right]$} & 290 & Dark grey & 70 & $\begin{array}{l}(39.23) \\
(39.25)\end{array}$ & $\begin{array}{c}2.61 \\
(2.67)\end{array}$ & $\begin{array}{c}4.11 \\
(4.16)\end{array}$ & $\begin{array}{c}5.83 \\
(5.87)\end{array}$ & $\begin{array}{c}28.79 \\
(28.99)\end{array}$ & 18 \\
\hline 9 & {$\left[\mathrm{Se} \mathrm{Pd}_{2}\left(\mathrm{SC}_{6} \mathrm{H}_{4} \mathrm{NH}_{2}-O\right)_{4}(\mathrm{SPh})_{4}\right]$} & 260 & Dark red & 68 & $\begin{array}{c}46.25 \\
(46.30)\end{array}$ & $\begin{array}{c}\mathbf{3 . 5 1} \\
(\mathbf{3 . 5 3})\end{array}$ & $\begin{array}{c}4.43 \\
(4.50)\end{array}$ & $\begin{array}{c}6.31 \\
(6.35)\end{array}$ & $\begin{array}{c}17.10 \\
(17.12)\end{array}$ & 12 \\
\hline 10 & {$\left[\mathrm{Se} \mathrm{Pt}_{2}\left(\mathrm{SC}_{6} \mathrm{H}_{4} \mathrm{NH}_{2}-O\right)_{4}(\mathrm{SPh})_{4}\right]$} & 280 & dark orange & 76 & $\begin{array}{c}41.06 \\
(41.11)\end{array}$ & $\begin{array}{c}\text { 3.10 } \\
(3.14)\end{array}$ & $\begin{array}{c}3.96 \\
(3.99)\end{array}$ & $\begin{array}{c}5.61 \\
(5.64)\end{array}$ & $\begin{array}{c}27.81 \\
(27.83)\end{array}$ & 14 \\
\hline
\end{tabular}

* CHN analysis was measure in Germany by Prof.Neoman frined of Prof.T.A.K.AL-Allaf 
Table 2: Electronic and IR spectral data of the compounds and complexes

\begin{tabular}{|c|c|c|c|c|c|c|c|}
\hline \multirow{2}{*}{$\begin{array}{c}\text { Compound } \\
\text { No. }\end{array}$} & \multicolumn{3}{|c|}{ U.V-Vis bands $\left(\mathrm{cm}^{-1}\right)$} & \multicolumn{4}{|c|}{ Selected IR bands $\left(\mathrm{cm}^{-1}\right)$} \\
\hline & 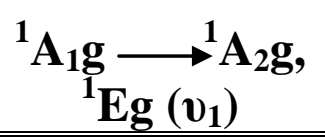 & ${ }^{1} A_{1} g \longrightarrow{ }^{1} B_{1} g\left(v_{2}\right)$ & C.T & $v(C-S)$ & $v(M-S)$ & $v(M-C l)$ & $\boldsymbol{v}\left(\mathrm{NH}_{2}\right)$ \\
\hline 1 & ---- & ---- & 33910,34000 & $1030_{(\mathrm{S})}$ & 350 & ---- & ---- \\
\hline 2 & ---- & ---- & 35000 & $1040_{(\mathrm{S})}$ & 340 & $\begin{array}{ll}--- \\
--\end{array}$ & 3390 \\
\hline 3 & 26100 & 28000 & 47250 & $1010_{(\mathrm{S})}$ & 360,400 & 290,330 & ---- \\
\hline 4 & 25100 & 28600 & 41900 & $1000_{(\mathrm{S})}$ & 380,400 & 300,330 & ---- \\
\hline 5 & 27000 & 28100 & 42000 & $1020_{(\mathrm{S})}$ & 340,380 & 300,310 & 3350 \\
\hline 6 & 24700 & 28590 & 36000 & $1025_{(\mathrm{S})}$ & 380,400 & 290,320 & 3290 \\
\hline 7 & 26500 & 28300 & 37000 & $999_{(\mathrm{S})}$ & 360,380 & ---- & ---- \\
\hline 8 & 27000 & 28250 & 36500 & $1005_{(\mathrm{S})}$ & 350,400 & $\begin{array}{l}---- \\
\end{array}$ & ---- \\
\hline 9 & 25600 & 28400 & 37300 & $1000_{(\mathrm{S})}$ & 360,380 & ---- & 3310 \\
\hline 10 & 24900 & 28100 & 40100 & $1010_{(\mathrm{S})}$ & 370,400 & $\begin{array}{ll}---- \\
\end{array}$ & 3340 \\
\hline
\end{tabular}

$\mathrm{s}=$ strong 


\section{$\underline{\text { References }}$}

1-P.Cassoux and L.Valade, "Inorganic Meterials" $2^{\text {nd }}$ ed.,John Wiley and Sons, Chichester,(1996).

2- A. J. Coober, D. Beljonne, R. H. Friend, J. K. Bredas, A. Charlton, N. Robertson, A.E.Underhill, M.Kurmoo and P.Day, Nature, 380, 144, (1996).

3- F.Bigoli, S.Curreli, P.Deplano, L.Leoni,M.L.Mercuri,M.A.Pellinghelli, A. Serpe and E.F.Trogu,J.Chem.Soc.Dalton Trans.,1985,(2002).

4- C.S.Winter, C.A.S.Hill and A.E.Underhill, Appl.Phys.Lett, 58, 107, (1991).

5- A.J.Blake, R.O.Gould, M.A.Halcrow, A.J.Holder, T.I.Hyde and M. Schöder, J.Chem.Soc.Dalton Trans.,3427,(1992).

6- C.T.Walsh and J.Reedijk,Inorg.Chem.,30,3700,(1991).

7- E.W.Abel,S.K.Bhargava and K.G.Orrel,Prog.Inorg.Chem.,32,1,(1984).

8- E.W.Abel,D.G.Evans,J.R.Koe,M.B.Hursthouse and M.Mazid, J.Chem. Soc. Dalton Trans.,663,(1992).

9- H.Wu and C.R.Lucas, Inorg.Chem.,31,2354,(1992).

10-S.Liu, C.R.Lucas, M.J.Newlands and J.P.Charland, Inorg. Chem., 29, 4380, (1990).

11- C.R.Lucas,S.Lin,M.J.Newlands and E.J.Gabe,Can.J.Chem., 58, 1357, (1990).

12- A.J.Deeming, M.N.Meah, P.B.Bates and M.B.Hursthouse, J.Chem. Soc. Dalton Trans.2193,(1988).

13- R.K.Agrwal and S.Prasad,Turk.J.Chem.,29,289,(2005).

14- N.H.Buttrus,Z.U.Jasim and T.A.K.AL-Allaf,Jordon J.Appl.Sci., 7(2), 92, (2005).

15- L.J.AL-Hayaly, N.H.Buttrus,F.Tarq and T.A.K.AL-Allaf, Jordon J. Appl. Sci.,7(1),64,(2005).

16- N.H.Buttrus,S.M.Mohammad and F.T.Saied, J.Educ.Sci., 18(3), 32, (2006).

17- N.H.Buttrus and E.H.Mohammad,Ref.J.Chem.(2006) Accepted.

18- F.F.Saied and D.G.Tuck,Inorg.Chim.Acta,59,1,(1982).

19- T.A.K.AL-Allaf, N.H.Buttrus and P.B.Hitchcock, Asian.J.Chem., 9, 187, (1997).

20- N.H.Buttrus and W.I.Alhamadani, J.Educ.Sci.,18(2),51,(2006).

21 - T.A.K.AL-Allaf,I.A.Mustafa and S.E.AL-Mukhtar, Transition Chem., 18,1,(1993).

22- T.W.Greean,R.Lieberman,N.Mitchell,J.A.Bauer and W.B.Connick, Inorg. Chem.,44(6),1955,(2005).

23- S.Yamada and K.Yamanonchi, Bull. Chem. Soc. (Japan), 42, 2543, (1969).

24- P. L. Goggin, R. J. Goodfellow and F.J.S.Reed, J. Chem. Soc. Dalton Trans., 1298,(1972). 